\title{
Analysis of Internal Control System of Trade Goods in Minang Motor Sport Stores Bengkulu City
}

\section{Analisis Sistem Pengendalian Internal Atas Persediaan Barang Dagang pada Toko Minang Motor Sport Kota Bengkulu}

\author{
Fatma Mulia'); Oni Yulianti2); Herlin²) \\ 1)Study Program of Accountancy, Faculty of Economic, Universitas Dehasen Bengkulu \\ ${ }^{2)}$ Department of Accountancy, Faculty of Economic, Universitas Dehasen Bengkulu \\ Email: ${ }^{1)}$ muliafatma97@gmail.com; ${ }^{2)}$ onidehasen@gmail.com; ${ }^{2)}$ herlin@unived.ac.id
}

How to Cite:

Mulia, F., Yulianti, O., Herlin. (2021). Analysis of Internal Control System of Trade Goods in Minang Motor Sport Stores Bengkulu City. EMAK: Jurnal Ekonomi Manajemen Akuntansi Dan Keuangan, 2(4). DOI: https://doi.org/10.53697/emak.v2i4

ARTICLE HISTORY

Received [12 Agust 2021]

Revised [25 Agust 2021]

Accepted [05 October 2021]

\section{KEYWORDS}

Internal Control System,

Inventory of Goods

This is an open access article under the $C C-B Y$-SA license

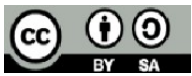

\section{ABSTRAK}

Tujuan penelitian untuk mengetahui untuk mengetahui sistem pengendalian internal atas persediaan barang dagang pada Toko Minang Motor Sport Kota Bengkulu. Metode pengumpulan data dalam penelitian ini adalah dengan menggunakan metode wawancara. Metode analisis yang digunakan adalah analisis deskriptif dengan jenis komparatif. Hasil penelitian menunjukkan Tidak adanya kesesuian antara teori Mulyadi (2016:488) dengan keadaan yang terjadi pada Toko Minang Motor Sport Kota Bengkulu untuk unsur organisasi, karena menurut teori Mulyadi untuk penghitungan fisik persediaan harus dilakukan oleh suatu panitia khusus yang dibentuk selain dari karyawan bagian gudang. Sedangkan yang terjadi pada Toko Minang Motor Sport Kota Bengkulu penghitungan fisik dilakukan langsung oleh bagian gudang. Untuk unsur system otorisasi dan prosedur pencataan adanya kesesuaian dan ketidak sesuaian antara teori Mulyadi (2016:488) dengan Toko Minang Motor Sport Kota Bengkulu, ketidaksesuaian terdapat pada daftar hasil perhitungan fisik persediaan ditandatangani oleh ketua panitia penghitungan fisik persediaan dan pencatatan hasil perhitungan fisik persediaan didasrkan atas kartu penhitungan fisik yang telah diteliti kebenarannya. Adanya kesesuaian antara teori Mulyadi (2016:488) dengan Toko Minang Motor Sport Kota Bengkulu untuk unsur praktik yang sehat, karena pada Toko Minang Motor Sport Kota Bengkulu kartu perhitungan fisik persediaan barang dagang telah diberi nomor berurut, pengecekan persediaan telah dilakukan dua kali oleh bagian penghitung persediaan dan selanjutnya oleh pengecek persediaan.

\section{ABSTRACT}

The research objective was to determine the internal control system for merchandise inventory at the Minang Motor Sport Store, Bengkulu City. The data collection method in this study is to use the interview method. The analytical method used is descriptive analysis with a comparative type. The results showed that there was no match between Mulyadi's (2016: 488) theory and the conditions that occurred at the Bengkulu City Minang Motor Sport Shop for organizational elements, because according to Mulyadi's theory, physical inventory counting had to be carried out by a special committee formed apart from warehouse employees. . Meanwhile, what 
happened at the Minang Motor Sport Store, Bengkulu City, the physical count was carried out directly by the warehouse department. For the elements of the authorization system and the recording procedure of the conformity and discrepancy between Mulyadi's theory (2016: 488) and the Minang Motor Sport Store in Bengkulu City, the discrepancy is in the list of physical inventory count results signed by the chairman of the physical inventory counting committee and the recording of the physical inventory count results is recorded. the correctness of the physical counting card that has been verified. There is compatibility between Mulyadi's (2016: 488) theory with the Minang Motor Sport Store in Bengkulu City for elements of healthy practice, because at the Minang Motor Sport Store, Bengkulu City, the physical counting of merchandise inventory cards has been numbered sequentially, inventory checking has been carried out twice by the department. inventory counters and subsequently by inventory checkers..

\section{PENDAHULUAN}

Semakin berkembangnya perusahaan maka kegiatan dan masalah yang dihadapi perusahaan semakin kompleks, sehingga semakin sulit bagi pihak pimpinan untuk melaksanakan pengawasan atau mengkoordinir secarra langsung terhadap seluruh aktivitas perusahaan. Hal ini dirasakan perlu adanya bantuan manajer-manajer yang professional sesuai dengan bidang yang ada dalam organisasi misalnya pemasaran, produksi, keuangan dan lain-lain. Perlu adanya struktur organisasi yang memadai, yang akan menciptakan suasana kerja yang sehat karena setiap staf bisa mengetahui dengan jelas dan pasti wewenang dan tanggung jawabnya serta dengan siapa ia bertanggung jawab.

Secara umum, perusahaan dagang dapat didefinisikan sebagai organisasi yang melakukan kegiatan usaha dengan membeli barang dari pihak/perusahaan lain kemudian menjualnya kembali kepada masyarakat. Setiap perusahaan pasti bertujuan untuk menghasilkan laba optimal agar dapat mempertahankan kelangsungan hidupnya, memajukan, serta mengembangkan usahanya ketingkat 3 yang lebih tinggi lagi. Salah satu unsur yang paling penting dalam perusahaan dagang adalah persediaan. Persediaan merupakan barang dagangan yang dibeli kemudian disimpan untuk selanjutnya dijual kembali dalam operasi. Perusahaan senantiasa memberi perhatian yang besar dalam persediaan (Mulyadi, 2016:88).

Tanpa persediaan barang dagangan perusahaan tidak dapat melakukan kegiatan penjualan. Penjualanpun juga akan terpengaruhi atas tersedianya barang dagangan atau persediaan tersebut. jika barang tidak tersedia berupa bentuk, jenis, mutu serta jumlah yang diinginkan pelanggan, maka penjualanpun akan ikut mengalami penurunan begitu juga sebaliknya. Oleh karena itu persediaan sangat perlu dijaga untuk kelangsungan kegiatan perusahaan yang bersangkutan. Baik prosedur penerimaan, pengeluaran, dan pencatatannya (Baridwan, 2014:101).

Pengendalian Internal persediaan merupakan fungsi manajerial yang sangat penting, karena pengendalian Internal atas persediaan ini banyak melibatkan investasi rupiah dan mempengaruhi efektivitas dan efisiensi kegiatan perusahaan. Oleh karena itu, pengendalian Internal atas persediaan barang dagang sangat diperlukan untuk mengurangi resiko terjadinya selisih, kehilangan, mengantisipasi kemungkinan terjadinya kecurangan dan memastikan bahwa prosedur telah dilakukan dengan baik sehingga kemudian dapat dibuatlah perbaikan (Arens, 2016:54).

Pelaksanaan sistem pengendalian internal harus memperhatikan struktur organisasi yang memisahkan tanggungjawab fungsional secara tegas. Struktur organisasi digunakan untuk pembagian tugas terhadap unit organisasi yang melaksanakan kegiatan pokok perusahaan. Pada persediaan barang harus adanya pembagian tugas yang jelas antara bagian penerima barang, pencatatan persediaan dan pengiriman barang. Sistem otorisasi dan prosedur pencatatan merupakan prosedur pencatatan yang memberikan perlindungan yang cukup terhadap aset, utang, pendapatan dan beban. Pencatatan yang jelas dalam perhitungan persediaan sangat erat sekali 
kaitannya dengan pengendaian internal, karena jika terjadi selisih persediaan barang maka dengan adanya pencatatan yang jelas akan memberikan penjelasan terhadap selisih persediaan yang terjadi (Rudianto, 2018:98).

Praktek yang sehat dalam melaksanakan tugas dan fungsi setiap unit organisasi, hal ini dapat dilakukan dengan cara penggunaan formulir bernomor, pemeriksaan mendadak, perputaran jabatan dan lain-lain. Hal ini akan membantu perusahaan dalam pelaksanaan pengendalian internal persediaan barang karena dengan adanya formulir yang bernomor akan memberikan kemudahan dalam pencarian data. Perputaran jabatan sangat penting sekali karena jabatan yang monoton akan mempengaruhi kecapakan karyawan dalam bekerja. Karyawan yang mutunya sesuai dengan tanggung jawabnya merupakan kriteria yang sangat penting sekali dalam sistem pengendalian internal, karena meskipun baiknya struktur organisasi, sistem otorisasi dan prosedur pencatatan serta berbagai cara yang diciptakan untuk mendorong praktik yang sehat semuanya terganung kepada manusia yang melaksanakannya (Mulyadi, 2016:155).

Toko Minang Motor Sport Kota Bengkulu merupakan salah satu usaha yang bergerak dalam penjualan ban dan velg mobil dan juga melayani service mobil. Selain itu Toko Minang Motor Sport Kota Bengkulu juga menjual berbagai macam spare part mobil. Untuk menjaga agar operasional tokonya tetap berjalan lancar maka Toko Minang Motor Sport Kota Bengkulu harus memperhatikan pengendalian persediaan barang. Karena persediaan barang yang banyak akan mengakibatkan penumpukan barang karena kurangnya penjualan dan modal tidak akan berputar.

Fenomena yang terjadi mengenai pengendalian interen persediaan barang pada Toko Minang Motor Sport Kota Bengkulu adalah belum ada keseragaman dalam penulisan nama barang, kesalahan menulis nama/merk/size pada barang yang keluar dan kesalahan mengeluarkan barang dari gudang. Hal ini disebabkan karena banyaknya jenis dan ukuran dari ban dan velg yang dijual Toko Minang Motor Sport Kota Bengkulu sehingga membaut admin menjadi bingung pada saat menginputkan barang baik pada saat pembelian maupuan pada saat penjualan. Selain itu, juga sering terjadi ketidak cocokan jumlah persediaan antara kartu persediaan dengan jumlah persediaan barang yang ada didalam program persediaan yang sudah terkomputerisasi, hal ini disebabkan karena ketidak telitian karyawan dalam penginputan barang.

\section{LANDASAN TEORI}

\section{Sistem Pengendalian Internal}

Dalam suatu perusahaan Sistem Pengendalian Internal sangat penting untuk diterapkan, guna mengawasi setiap kegiatan yang dilakukan perusahaan untuk melindungi kekayaan perusahaan. Menurut Mulyadi (2016:129) Sistem Pengendalian Internal adalah "Sistem Pengendalian Internal meliputi struktur organisasi, metode dan ukuran - ukuran yang dikoordinasikan untuk menjaga kekayaan organisasi, mengecek ketelitian, dan keandalan data akuntansi, mendorong efesiensi dan mendorong dipatuhinya kebijakan manajemen". Menurut Susanto (2017:98) pengendalian internal merupakan semua metode, kebijakan dan prosedur organisasi yang menjamin keamanan harga kekayaan perusahaan, akurasi dan kelayakan data manajemen serta standar operasi manajemen lainnya. Pengendalian internal sangat erat sekali hubungannya dengan prosedur organisasi, metode yang ditetapkan oleh perusahaan yang layak digunakan oleh perusahan dalam penentuan standar dalam bekerja dan dijadikan sebagai patokan yang harus dipatuhi.

\section{Persediaan Barang}

Persediaan barang merupakan sejumlah barang-barang yang disediakan oleh perusahaan untuk proses produksi, serta barang-barang jadi yang disediakan untuk memenuhi kebutuhan atau permintaan konsumen. Fungsi persediaan barang pada perusahaan industri berbeda dengan persediaan barang pada perusahaan dagang. Menurut Mulyadi (2016:463) persediaan produk jadi, persdiaan produk dalam proses, persediaan bahan baku, persediaan bahan penolong, persediaan 
perlengkapan pabrik dan persediaan suku cadang. Dalam perusahaan dagang persediaan hanya terdiri dari satu jenis yaitu persediaan barang dagang yang merupakan barang yang dibeli untuk dijual kembali,

Menurut Assauri (2014:50), menerangkan bahwa persediaan adalah sebagai suatu aktiva lancar yang meliputi barang - barang milik perusahaan dengan maksud untuk dijual dalam suatu periode usaha normal atau persediaan barang - barang yang masih dalam pekerjaan proses produksi ataupun persediaan bahan baku yang menunggu penggunaanya dalam suatu proses produksi. Menurut Baridwan (2016:149), pengertian persediaan barang secara umum istilah persediaan barang dipakai untuk menunjukan barang-barang yang dimiliki untuk dijual kembali atau digunakan untuk memproduksi barang-barang yang akan dijual. Jadi persediaan barang merupakan sejumlah barang-barang yang disediakan oleh perusahaan untuk proses produksi, serta barang-barang jadi yang disediakan untuk memenuhi kebutuhan atau permintaan konsumen. Fungsi persediaan barang pada perusahaan industri berbeda dengan persediaan barang pada perusahaan dagang.

\section{Metode Penilaian Persediaan}

Menurut Kieso et al, (2017:92), metode identifikasi khusus yaitu mengidentifikasi masingmasing barang yang dijual dan masing-masing barang yang tersedia untuk dijual. Metode ini hanya digunakan dalam praktik apabila masing-masing persediaan dapat diidentifikasi secara khusus dan dapat dipisahkan untuk setiap pembelian. Oleh karena itu, banyak perusahaan hanya menerapkan metode ini pada persediaan yang jumlahnya relatif sedikit. Dalam metode identifikasi khusus, arus biaya harus sesuai dengan arus barang dan untuk mengatasi kesulitan dalam metode ini, digunakanlah metode yang arus biaya tidak perlu sesuai dengan arus barang.

\section{METODE PENELITIAN}

\section{Metode Analisis}

Jenis penelitian yang digunakan oleh peneliti adalah penelitian deskriptif dengan jenis komparatif (perbandingan). Pengertian metode deskriptif menurut Nazir (2013:54) adalah suatu metode dalam meneliti status kelompok manusia, suatu objek, suatu set kondisi, suatu sistem pemikiran, ataupun suatu kelas peristiwa pada masa sekarang. Dalam metode deskriptif peneliti bisa saja membandingkan fenomena-fenomena tertentu sehingga merupakan suatu studi komparatif..

Adapun metode analisis yang digunakan dalam penelitian ini adalah ;

1. Menghitung persediaan barang dengan metode FIFO, LIFO dan Average. Dalam perhiungan persediaan maka digunakan tabel 1. sebagai berikut:

Tabel 1. Perhitungan Persediaan Barang

\begin{tabular}{|c|c|c|c|c|c|c|c|c|c|}
\hline \multirow{2}{*}{ Tanggal } & \multicolumn{3}{|c|}{ Pembelian } & \multicolumn{3}{c|}{ Harga pokok penjualan } & \multicolumn{4}{c|}{ Persediaan } \\
\cline { 2 - 10 } & Unit & Harga/Unit & Total & Unit & Harga/Unit & Total & Unit & Harga/Unit & Total \\
\hline & & & & & & & & & \\
\hline & & & & & & & & & \\
\hline & & & & & & & & & \\
\hline & & & & & & & & & \\
\hline & & & & & & & & & \\
\hline & & & & & & & & & \\
\hline
\end{tabular}

a. Metode FIFO

Dalam penerapan metode FIFO berarti perusahaan akan menggunakan persediaan barang yang lama/pertama masuk untuk dijual terlebih dahulu. Jadi biasanya persediaan akhir barang dagangan akan dinilai dengan nilai perolehan persediaan yang terakhir masuk.

b. Metode LIFO 
Dalam penerapan metode LIFO berarti perusahaan akan menggunakan persediaan barang yang baru/terakhir masuk untuk dijual terlebih dahulu. Jadi biasanya persediaan akhir barang dagangan akan dinilai dengan nilai perolehan persediaan yang pertama atau awal masuk.

c. Metode Average

Dalam penerapan metode Average berarti perusahaan akan menggunakan persediaan barang yang ada di gudang untuk dijual tanpa memperhatikan barang mana yang masuk lebih awal atau akhir. Jadi persediaan akhir barang dagangan akan dinilai dengan nilai perolehan persediaan rata-rata yang masuk. Membandingkan teori yang digunakan antara sistem pengendalian internal menurut Mulyadi (2016:488), dengan sistem pengendalian internal persediaan barang pada Toko Minang Motor Sport Kota Bengkulu. Menggunakan bagan alur/flow chat mengenai sistem pengelolaan barang dagang pada Minang Motor Sport kota Bengkulu

\section{HASIL DAN PEMBAHASAN}

\section{Hasil dan Pembahasan}

Berdasarkan hasil analisis maka pengendalian interen persediaan barang pada Toko Minang Motor Sport Kota Bengkuludapat dilihat pada Tabel 2. berikut:

Tabel 2. Hasil Perbandingan Antara Sistem Pengendalian Intern Persediaan Barang Dagang Menurut Mulyadi (2016:488) dengan Toko Minang Motor Sport Kota Bengkulu

\begin{tabular}{|c|c|c|c|}
\hline Unsur Pengendalian & Mulyadi (2016:488) & $\begin{array}{l}\text { Toko Minang Motor Sport } \\
\text { Kota Bengkulu }\end{array}$ & Keterangan \\
\hline \multirow[t]{2}{*}{ Organisasi } & $\begin{array}{l}\text { Perhitungan fisik persediaan harus } \\
\text { dilakukan oleh suatu panitia yang } \\
\text { terdiri dari fungsi pemegang kartu } \\
\text { perhitungan fisik, fungsi penghitung, } \\
\text { dan fungsi pengecek. }\end{array}$ & $\begin{array}{l}\text { Penghitungan fisik } \\
\text { persediaan dilakukan oleh } \\
\text { dua fungsi yaitu fungsi } \\
\text { penghitungan dan fungsi } \\
\text { pengecek. }\end{array}$ & Tidak Sesuai \\
\hline & $\begin{array}{l}\text { Panitia yang dibentuk harus terdiri } \\
\text { dari karyawan selain karyawan fungsi } \\
\text { gudang dan fungsi akuntansi } \\
\text { persediaan, karena karyawan di } \\
\text { kedua fungsi inilah yang justru } \\
\text { dievaluasi tanggung jawabnya atas } \\
\text { persediaan. }\end{array}$ & $\begin{array}{l}\text { Perusahaan membentuk tim } \\
\text { penghitungan fisik yang } \\
\text { merupakan karyawan dari } \\
\text { fungsi gudang }\end{array}$ & Tidak Sesuai \\
\hline \multirow[t]{4}{*}{$\begin{array}{c}\text { Sistem Otorisasi dan } \\
\text { Prosedur } \\
\text { Pencatatan }\end{array}$} & $\begin{array}{l}\text { Daftar hasil perhitungan fisik } \\
\text { persediaan ditandatangani oleh } \\
\text { Ketua Panitia Penghitungan Fisik } \\
\text { Persediaan. }\end{array}$ & $\begin{array}{l}\text { Ditandatangani oleh } \\
\text { penghitung fisik persediaan }\end{array}$ & Tidak Sesuai \\
\hline & $\begin{array}{l}\text { Pencatatan hasil penghitungan fisik } \\
\text { persediaan didasarkan atas kartu } \\
\text { penghitungan fisik yang telah diteliti } \\
\text { kebenarannya oleh pemegang kartu } \\
\text { penghitungan fisik. }\end{array}$ & $\begin{array}{l}\text { Fungsi pengecek merangkap } \\
\text { sebagai fungsi pemegang } \\
\text { kartu penghitungan fisik }\end{array}$ & Tidak Sesuai \\
\hline & $\begin{array}{l}\text { Harga satuan yang dicantumkan } \\
\text { dalam daftar hasil penghitungan fisik } \\
\text { berasal dari kartu persediaan yang } \\
\text { bersangkutan. }\end{array}$ & $\begin{array}{l}\text { Harga satuan yang } \\
\text { dicantumkan dalam daftar } \\
\text { hasil penghitungan fisik } \\
\text { berasal dari kartu persediaan } \\
\text { yang bersangkutan }\end{array}$ & Sesuai \\
\hline & $\begin{array}{l}\text { Adjustment terhadap kartu } \\
\text { persediaan didasarkan pada } \\
\text { informasi (kuantitas maupun harga } \\
\text { pokok total) tiap jenis persediaan }\end{array}$ & $\begin{array}{l}\text { Adjusment terhadap kartu } \\
\text { persediaan didasarkan pada } \\
\text { tiap jenis persediaan dalam } \\
\text { daftar perhitungan fisik }\end{array}$ & Sesuai \\
\hline
\end{tabular}


p-ISSN 2798-0499 e-ISSN 2798-0502

\begin{tabular}{|c|c|c|c|}
\hline & $\begin{array}{l}\text { yang tercantum dalam daftar } \\
\text { penghitungan fisik. }\end{array}$ & & \\
\hline \multirow[t]{4}{*}{ Praktik yang Sehat } & $\begin{array}{l}\text { Kartu penghitungan fisik bernomor } \\
\text { urut tercetak dan penggunaannya } \\
\text { dipertanggungjawabkan oleh fungsi } \\
\text { pemegang kartu penghitungan fisik. }\end{array}$ & $\begin{array}{l}\text { Kartu penghitungan fisik } \\
\text { tidak bernomor urut tercetak } \\
\text { dan penggunaannya } \\
\text { dipertanggungjawab-kan } \\
\text { oleh pihak yang memilikinya. }\end{array}$ & Tidak Sesuai \\
\hline & $\begin{array}{l}\text { Penghitungan fisik setiap jenis } \\
\text { persediaan dilakukan dua kali secara } \\
\text { independen, pertama kali oleh } \\
\text { penghitung dan kedua kali oleh } \\
\text { pengecek }\end{array}$ & $\begin{array}{l}\text { Tidak adanya penghitungan } \\
\text { stok dua kali }\end{array}$ & Tidak Sesuai \\
\hline & $\begin{array}{l}\text { Kuantitas dan data persediaan yang } \\
\text { lain yang tercantum dalam bagian ke- } \\
3 \text { dan bagian ke-2 kartu } \\
\text { penghitungan fisik dicocokkan oleh } \\
\text { fungsi pemegang kartu penghitungan } \\
\text { fisik sebelum data yang tercantum } \\
\text { dalam bagian ke-2 kartu } \\
\text { penghitungan fisik dicatat dalam } \\
\text { daftar hasil penghitungan fisik }\end{array}$ & $\begin{array}{l}\text { Kuantitas data yang lain } \\
\text { tercantum dalam kartu } \\
\text { penghitungan fisik dicatat } \\
\text { dalam daftar hasil } \\
\text { penghitungan fisik }\end{array}$ & Sesuai \\
\hline & $\begin{array}{l}\text { Peralatan dan metode yang } \\
\text { digunakan untuk mengukur dan } \\
\text { menghitung kuantitas persediaan } \\
\text { harus dijamin ketelitiannya }\end{array}$ & $\begin{array}{l}\text { Peralatan dan metode yang } \\
\text { digunakan untuk mengukur } \\
\text { dan menghitung kuantitas } \\
\text { persediaan telah terjamin } \\
\text { ketelitiannya }\end{array}$ & Sesuai \\
\hline
\end{tabular}

\section{Pembahasan}

Berdasarkan hasil penelitian mengenai system pengendalian interen persediaan barang pada Toko Minang Motor Sport Kota Bengkulu dengan cara membandingkan anatara system pengendalian interen menurut Mulyadi (2016:488) dengan pengendalian interen yang terjadi pada Toko Minang Motor Sport Kota Bengkulu yang dilihat dari tiga unsur sebagai berikut :

1. Organisasi

Adanya ketidaksesuaian antara teori yang disampaikan Mulyadi (2016:488) dengan Toko Minang Motor Sport Kota Bengkulu. Pada perhitungan fisik persediaan menurut teori Mulyadi harus dilakukan oleh satu panitia yang terdiri dari fungsi pemegang kartu perhitungan fisik, fungsi penghitung dan fungsi pengecek. Sedangkan yang terjadi pada Toko Minang Motor Sport Kota Bengkulu perhitungan fisik persediaan dihitung oleh dua fungsi yaitu fungsi penghitung dan fungsi pengecek. Untuk anitia yang dibentuk harus terdiri dari karyawan selain karyawan gudang dan karyawan fungsi akuntansi persedia juga terdapat ketidaksesuaian antara teori Mulyadi dengan Toko Minang Motor Sport Kota Bengkulu karena pada Toko Minang Motor Sport Kota Bengkulu perhitungan fisik persediaan dilakukan lansung oleh karyawan Toko Minang Motor Sport Kota Bengkulu yang merupakan bagian dari fungsi gudang.

2. Sistem Otorisasi dan Proedur Pencatatan

Untuk system otorisasi dan prosedur pencatatan adanya kesesuaian dan ketidak sesuaian antara teori Mulyadi (2016:488) dengan yang terjadi pada Toko Minang Motor Sport Kota Bengkulu. Ketidaksesuaian terlihat ada daftar hasil perhitungan fisik persediaan ditandatangani oleh ketua panitia perhitungan fisik sedangkan yang terjadi pada Toko Minang Motor Sport Kota Bengkulu hasil perhitungan ditandatanagni oleh penghitung persediaan fisik karena pada saat perhitungan persediaan fisik tidak adanya pembentukan panitia khusus untuk menghitung persediaan. Ketidaksesuaian juga terlihat pada pencatatn hasil perhitungan fisik persediaan didasarkan atas kartu perhitungan fisik yang telah diteleti kebenarannya oleh pemegang kartu persediaan, karena pada Toko Minang Motor Sport Kota Bengkulu kartu 
persediaan dipegang langsung oleh karyawan pada fungsi gudang. Namun adanya kesesuaian antara teori Mulyadi dengan Toko Minang Motor Sport Kota Bengkulu ada harga satuan yang dicantumkan dalam daftar hasil perhitungan fisik berasal dari kartu persediaan yang bersangkutan dan adjustment terhadap kartu persediaan pada informasi tiap jenis persediaan yang tercantum dalam daftar perhitungan fisik.

3. Praktik Yang Sehat

Untuk praktik yang sehat adanya kesesuaian antara teori Mulyadi (2016:488) dengan keadaan yang ada pada Toko Minang Motor Sport Kota Bengkulu karena semua kartu perhitungan fisik atau kartu persediaan telah diberi nomor urut dan disesuiakan dengan nama masing-masing barang dagang. Pada perhitungan fisik persediaan akan dilakukan dua kali pertama dilakukan oleh bagian penghitung persediaan dan kemudian akan dilakukan oleh bagian pengecek persediaan, sehingga jika ada selisih barang akan diketehuai penyebab terjadinya selisih persediaan tersebut. Setelah dilakukan penghitungan fisik persdiaan maka akan dilakukan pencocokan antara barang yang ada, kartu perediaan dan juga jumlah persediaan yang ada di software computer. Peralatan dan metode yang digunakan utnu mengukur perhitungan kuantitas persdiaan telah terjamin karena dilakukan sesuai prosedur.

\section{KESIMPULAN DAN SARAN}

\section{Kesimpulan}

1. Tidak adanya kesesuian antara teori Mulyadi (2016:488) dengan keadaan yang terjadi pada Toko Minang Motor Sport Kota Bengkulu untuk unsur organisasi, karena menurut teori Mulyadi untuk penghitungan fisik persediaan harus dilakukan oleh suatu panitia khusus yang dibentuk selain dari karyawan bagian gudang. Sedangkan yang terjadi pada Toko Minang Motor Sport Kota Bengkulu penghitungan fisik dilakukan langsung oleh bagian gudang.

2. Untuk unsur system otorisasi dan prosedur pencataan adanya kesesuaian dan ketidak sesuaian antara teori Mulyadi (2016:488) dengan Toko Minang Motor Sport Kota Bengkulu, ketidaksesuaian terdapat pada daftar hasil perhitungan fisik persediaan ditandatangani oleh ketua panitia penghitungan fisik persediaan dan pencatatan hasil perhitungan fisik persediaan didasrkan atas kartu penhitungan fisik yang telah diteliti kebenarannya.

3. Adanya kesesuaian antara teori Mulyadi (2016:488) dengan Toko Minang Motor Sport Kota Bengkulu untuk unsur praktik yang sehat, karena pada Toko Minang Motor Sport Kota Bengkulu kartu perhitungan fisik persediaan barang dagang telah diberi nomor berurut, pengecekan persediaan telah dilakukan dua kali oleh bagian penghitung persediaan dan selanjutnya oleh pengecek persediaan.

\section{Saran}

1. Pihak Toko Minang Motor Sport Kota Bengkulu harus meningkatkan sistem pengendalian intern yang ada di perusahaan untuk mengatasi permasalahan kehilangan persediaan barang dan menerapkan fungsi gudang.

2. Sistem otorisasi dan prosedur pencatatan yang dilakukan harus sesuai dengan fungsi dan tanggung jawab masing-masing fungsi pihak perusahaan harus menerapkan sistem otorisasi untuk setiap transaksi yang terjadi sehingga setiap kegiatan yang terjadi dapat dipertanggung jawabkan dan ada buktinya.

3. Praktik yang sehat harus dilakukan dengan cara melakukan perhitungan fisik persediaan dilakukan dua sampai tiga kali setiap bulannya bukan hanya sesekali saja agar menjamin ketelitian karyawan terhadap persediaan barang dagangan tersebut dan dapat mengurangi tingkat hilangan persediaan barang dagangan dan menjaga keamanan harta kekayaan perusahaan yang menjadi asset yang paling penting 


\section{DAFTAR PUSTAKA}

Agoes, Sukrisno. 2014. Petunjuk Praktis Akuntansi. Jakarta: Salemba Empat.

Arens, Alvin A. Elder, Randal J dan Beasley Mark S. 2016. Auditing dan Jasa Assurance Pendekatan Terintegrasi. Jakarta: Erlangga

Assauri, Sofyan. 2014. Manajemen Operasi dan Produksi. Edisi revisi. BPFE, Yogyakarta

Baridwan, Zaki. 2016. Sistem Informasi Akuntasi, Edisi ke-2. BPFE, Yogyakarta.

Baridwan. Zaki. 2014. Akuntansi Intermediate. Edisi 8. BPFE : Yogyakarta

Haryati, 2013. Analisis Sistem Pengendalian Intern Terhadap Penjualan dan Penerimaan Kas pada

PT. Prioritas Arga Makmur. Skripsi. Universitas Dehasen Bengkulu

Mulyadi. 2016. Sistem Akuntansi. Edisi Keempat. Cetakan Kelima . Salemba Empat. : Jakarta.

Nazir, Mohammad. 2013. Metode Penelitian. Bogor: Ghalia Indonesia

Rajagukguk, Martha. 2014. Analisis Sistem Pengendalian Intern Terhadap Penerimaan Kas Pada PT.

Pegadaian (Persero) Cabang Bengkulu. Skripsi. Universitas Dehasen Bengkulu

Reeve, James. S. Warren, Carl. et.al. 2015. Pengantar Akuntansi Adaptasi Indonesia. Jakarta: Salemba Empat

Rudianto. 2018. Pengantar Akuntansi. Jakarta. Erlangga.

Sartono. Agus. 2015. Manajemen Keuangan Teori dan Aplikasi. BPFE, Yogyakarta

Sugiyono, 2015. Metode Kuantitatif, Kualitatif dan R\&D. Bandung: Alfabeta

Susanto, Azhar. 2017. Sistem Informasi Akuntansi Konsep dan Pengembangan Berbasis Komputer. Bandung: Linggar Jaya

Syamsuddin. Lukman. 2017. Manajemen Keuangan Perusahaan, Konsep Aplikasi dalam Perencanaan, pengawasan dan Pengambilan Keputusan. PT. Raja Grafindo Persada: Jakarta.

Warren, dkk. 2016. Pengantar Akuntansi Adaptasi Indonesia. Jakarta: Salemba Empat

Wulandari, Fitri. 2018. Analisa Pengendalian Internal Atas Sistem Persediaan Barang Dagang Pada Toko Bintang Timur Bangkit Mulia Semarang. Akuntabel ISSN Print: 0216-7743 ISSN Online: 2528-113594

Yamit, Zulian. 2014. Manajemen Produksi dan Operasi, Second Edition. Ekonosia Yogyakarta 